\title{
NILAI PERUSAHAAN: HUBUNGAN KEPUTUSAN INVESTASI, KEPUTUSAN PENDANAAN DAN KEBIJAKAN DIVIDEN PERUSAHAAN JASA
}

\author{
Nur Syamsu', Anwar*2 \\ Program Studi Manajemen, STIEM Bongaya Makassar ${ }^{1}$ \\ Program Studi Akuntansi, STIEM Bongaya Makassar ${ }^{2}$ \\ e-mail: nursyamsu@gmail.com ${ }^{1}$, anwar@stiem-bongaya.ac.id ${ }^{2}$
}

\begin{abstract}
Abstrak
Tujuan dari penelitian ini adalah ingin menguji kaitan nilai perusahaan dengan menggunakan keputusan investasi, keputusan pendanaan dan kebijakan dividen. Data yang digunakan adalah data dari perusahaan jasa sektor perdagangan diperoleh dari Bursa Efek Indonesia periode tahun 2018 dari situs website https://idx.co.id serta dengan menelusuri website perusahaan yang mempublikasikan laporan keberlanjutan perusahaan. Populasi pada penelitian ini adalah keseluruhan perusahaan sektor jasa yang terdaftar di Bursa Efek Indonesia tahun 2018 yang berjumlah 420 perusahaan jasa dengan teknik purposive sampling sehingga total sampel adalah data keuangan dari 103 perusahan jasa yang terdaftar di Bursa Efek Indonesia tahun 2018. Alat analisis yang digunakan analisis linier berganda dengan SEM-PLS. Partial Least Square (PLS). Hasil penelitian menemukan bahwa keputusan investasi berpengaruh signifikan terhadap nilai perusahaan. Sedangkan keputusan pendanaan dan keputusan dividen tidak berpengaruh terhadap nilai perusahaan.
\end{abstract}

Kata kunci : keputusan investasi, keputusan pendanaan, keputusan dividen, nilai perusahaan.

\section{Abstract}

The purpose of this research is to examine the relationship between firm value using investment decisions, funding decisions and dividend policies. The data used is data from trading sector service companies obtained from the Indonesia Stock Exchange for the 2018 period from the https://https://id website and by browsing the websites of companies that open company reports. The population in this study are all service sector companies listed on the Indonesia Stock Exchange in 2018 totaling 420 service companies with purposive sampling technique so that the total sample is financial data from 103 service companies listed on the Indonesia Stock Exchange in 2018. The analytical tool used is analysis. multiple linearity with SEM-PLS. Partial Least Square (PLS). The results of the study found that investment decisions have a significant effect on firm value. Meanwhile, the source decision and dividend decision have no effect on firm value.

Keywords : investment decisions, the source decision, dividend decision, firm value.

\section{PENDAHULUAN}

Emiten perlu menjaga dan meningkatkan nilai perusahaan, agar transaksi bursa (listing) dapat terus eksis dan tetap menarik bagi investor. Nilai perusahaan tinggi dapat mencerminkan kesejahteraan pemegang saham perusahaan. Calon investor yang ingin menanamkan dananya di perusahaan, pasti akan mempertimbangkan nilai perusahaannya. Jika suatu perusahaan ditandai dengan tingkat pengembalian investasi yang tinggi bagi pemegang saham, maka nilai perusahaan di pasar modal akan meningkat. Nilai perusahaan yang tercatat di bursa tercermin dari harga saham perusahaan tersebut (Purnomo, 2019).

Tujuh sektor jasa menunjukkan pertumbuhan negatif pada tahun 2020 dan mencapai puncaknya pada triwulan II tahun 2020. Sebagai contoh, sektor akomodasi, 
makanan dan minuman mengalami pertumbuhan sebesar 6,36\% pada kuartal keempat 2019, tetapi menurun hingga $22 \%$ pada kuartal kedua 2020. Indonesia tidak seburuk yang awalnya diperkirakan, tetapi sedang dalam resesi. Banyak sektor jasa telah menunjukkan tren pemulihan. Pada triwulan II 2020, sektor ritel, pengangkutan, pergudangan, penginapan, makanan dan minuman, serta jasa keuangan masing-masing tumbuh sebesar 7,5\%, 30,8\%, 22,02\%, dan 1,05\%. Pada triwulan IV 2020, pulih menjadi $3,64 \%, 13,42 \%, 8,88 \%$ dan 2,37\% (www.binis.com,2021). Fakta ini tentunya akan memengaruhi nilai perusahaan jasa yang tercatat di bursa efek.

Nilai sebuah perusahaan dapat diukur dengan berbagai cara, termasuk harga saham dari perusahaan. Harga saham merupakan sumber informasi bagi investor. Dalam penelitian ini, nilai perusahaan ditentukan dengan menggunakan rasio Price to Book Value (PBV). PBV menunjukkan bahwa perusahaan memiliki kemampuan untuk menciptakan nilai perusahaan terkait dengan modal investasi (Chasanah \& Adhi, 2018). PBV adalah rasio harga saham perusahaan terhadap nilai buku, dimana menunjukkan nilai harga per saham dibandingkan dengan nilai buku per saham.

PBV yang tinggi menunjukkan bahwa perusahaan telah memperoleh harga saham dan menguntungkan untuk investasi. Semakin tinggi PBV sebesar maka semakin baik nilai perusahaan tersebut, sehingga dapat menarik investor untuk menanamkan modalnya pada perusahaan tersebut (Febriana \& Djawahir, 2016). Nilai PBV yang lebih besar dari 1 menunjukkan bahwa perusahaan dalam kondisi baik, artinya nilai pasar atau harga saham lebih tinggi dari nilai buku perusahaan. Di sisi lain, PBV lebih rendah dari 1 mencerminkan nilai perusahaan yang kurang menguntungkan, yaitu harga saham lebih rendah dari nilai buku, dan minat investor untuk berinvestasi di perusahaan juga berkurang (Ramadhani, 2016).

Keputusan investasi sebagai salah satu faktor yang memengaruhi nilai perusahaan. Keputusan investasi menyangkut keputusan penyaluran dana dan sumber dana di dalam dan di luar perusahaan. Kenaikan nilai perusahaan dari investasi ini akan tercermin dari kenaikan harga saham (Languju, 2016). Dalam penelitian ini keputusan investasi yang diukur menggunakan Price Earning Ratio (PER). Peningkatan nilai perusahaan dari investasi ini akan tercermin pada meningkatnya harga saham. Dengan kata lain, keputusan investasi harus dinilai dalam hubungannya dengan kemampuannya dalam menghasilkan keuntungan yang sama atau lebih besar dari yang di syaratkan oleh pemilik modal (Ayuningtyas et al., 2020). Investor akan melihat bagaimana cara dari manajemen perusahaan dalam mengelola asset atau aktiva yang dimiliki oleh perusahaan karena keputusan investasi yang diambil akan berdampak pada profit yang dihasilkan perusahaan (Wildan \& Yulianti, 2021).

Dasar teori pengambilan keputusan investasi adalah teori sinyal. Teori sinyal menunjukkan bahwa pengeluaran investasi mengirimkan sinyal positif ke pertumbuhan masa depan perusahaan, sehingga menaikkan harga saham sebagai indicator nilai Perusahaan. Teori ini menunjukkan bahwa pengeluaran investasi yang dilakukan oleh perusahaan yang mengirimkan sinyal, terutama kepada investor dan kreditur yang akan mengakibatkan pertumbuhan perusahaan di masa depan.

Hasil penelitian (Somantri \& Sukardi, 2019) dan (Kurniawan, 2020) menemukan bahwa keputusan investasi berpengaruh signifikan terhadap nilai perusahaan. Keputusan investasi harus dievaluasi dan dihubungkan dengan resiko dan hasil yang diharapkan, bagi investor, pertumbuhan perusahaan yang baik sangat menguntungkan karena modal yang diinvestasikan dapat memberikan pengembalian di masa depan (Effendy \& 
Handayani, 2020). Namun, (Bahrun et al., 2020) menemukan bahwa keputusan investasi tidak berpengaruh signifikan terhadap nilai perusahaan. Maka diajukan :

H1 : Keputusan investasi berpengaruh positif dan signifikan terhadap nilai perusahaan.

Dunia usaha sangat tergantung dengan dana, maka keputusan pendanaan memengaruhi nilai dari perusahaan. Keputusan pendanaan adalah keputusan tentang mencari sumber dana untuk mendanai investasi dan menentukan berapa banyak kombinasi sumber yang akan digunakan. Dana berasal dari sumber internal, seperti laba ditahan, ekuitas dan kas, dan beberapa berasal dari sumber eksternal, seperti utang dan ekuitas. Keputusan pembiayaan dapat diartikan sebagai keputusan tentang struktur keuangan (financial structure). Tujuan Keputusan pendanaan adalah agar perusahaan menentukan sumber pendanaan maksimum dari dari nilai perusahaan yang tercermin pada harga sahamnya dan menyediakan pendanaan untuk pilihan investasi yang berbeda. Struktur keuangan peusahaan merupakan komposisi dari keputusan pendanaan yang meliputi utang jangka pendek, utang jangka panjang dan modal sendiri.

Menurut teori pecking order, dana eksternal lebih disukai dalam bentuk hutang daripada modal. Ada dua alasan ekuitas, yaitu pertimbangan biaya emisi, di antaranya biaya emisi obligasi lebih tinggi dan lebih murah daripada biaya penerbitan saham baru. Hal ini dikarenakan adanya penerbitan saham baru akan menurunkan harga saham lama. Alasan kedua adalah manajer khawatir, Penerbitan saham baru dapat diinterpretasikan oleh investor sebagai berita buruk, yang mengarah ke Nilai perusahaan turun. Manajer dapat menggunakan hutang sebagai sinyal yang lebih terpercaya untuk para investor. Ini karena perusahaan yang meningkatkan hutang dapat dipandang sebagai perusahaan yang yakin dengan prospek perusahaan di masa yang akan datang.

Hasil penelitian (Mubarokah \& Indah, 2021) dan (Fitiriawati et al., 2021) menemukan bahwa keputusan pendanaan berpengaruh terhadap nilai perusahaan. Ketika pembiayaan didanai dari utang maka nilai perusahan akan mengalami kenaikan karena adanya faktor bebas pajak, yaitu perusahaan dapat menghitung bunga yang dibayarkan kepada kreditur ketika menghitung penghasilan kena pajak, yang berdampak pada pembayaran pajak yang lebih rendah. Di sisi lain, penambahan dana dari laba ditahan atau penerbitan saham baru menyebabkan risiko keuangan perusahaan lebih rendah dari penerbitan surat utang (Bahrun et al., 2020). Namun penelitian (Salama et al., 2019) menemukan bahwa keputusan pendanaan tidak berpengaruh terhadap nilai perusahaan. Maka diajukan :

$\mathrm{H} 2$ : keputusan pendanaan berpengaruh positif dan signifikan terhadap nilai perusahaan.

Selain keputusan investasi dan pendanaan, keputusan dividen merupakan suatu masalah yang sering dihadapi oleh perusahaan. Dividen merupakan alasan bagi investor dalam menanamkan investasinya, dimana dividen merupakan pengembalian yang akan diterimanya atas investasinya dalam perusahaan. Tujuan utama para investor yakni meningkatkan kesejahteraan dengan mengharapkan pengembalian dalam bentuk dividen, sedangkan perusahaan berharap terus tumbuh demi mempertahankan kelangsungannya sekaligus memberikan kesejahteraan kepada investornya, sehingga kebijakan dividen penting dalam pemenuhan harapan 
pemegang saham terhadap dividen dengan tidak menghambat sisi lain dari pertumbuhan perusahaan.

Kebijakan dividen berkaitan dengan kebijakan mengenai seberapa besar laba yang diperoleh perusahaan akan didistribusikan kepada pemegang saham (Fitriana, 2014). Perusahaan yang dapat memberikan dividen tinggi juga akan mendapatkan nilai kepercayaan yang tinggi dari para investor, karena investor lebih menyukai kepastian tentang returns investasinya dan mengantisipasi risiko ketidakpastian tentang kebangkrutan perusahaan.

Hasil penelitian (Salama et al., 2019) dan (Sugiyarti \& Ramadhani, 2019) menemukan bahwa keputusan dividen berpengaruh signifikan terhadap nilai perusahaan. Membagikan laba bersih yang sangat besar kepada pemegang saham dapat menyebabkan investor berlomba-lomba untuk membeli saham di perusahaan tersebut karena investor yakin perusahaan tersebut memiliki prospek yang baik (Rinnaya et al., 2016). Namun, hasil penelitian (Suryandani, 2018) menemukan bahwa keputusan dividen tidak berpengaruh signifikan terhadap nilai perusahaan. Maka diajukan hipotesis :

H3 : keputusan dividen berpengaruh positif dan signifikan terhadap nilai perusahaan.

Adapun tujuan dari penelitian ini adalah ingin menguji kaitan nilai perusahaan dengan menggunakan keputusan investasi, keputusan pendanaan dan kebijakan dividen.

\section{METODE PENELITIAN}

Metode penelitian kuantitatif digunakan dalam penelitian ini untuk menguji hubungan antar variabel, memberikan deskripsi statistik, memperkirakan dan memprediksi hasil. Data yang digunakan dalam penelitian ini adalah data dari perusahaan jasa sektor perdagangan diperoleh dari Bursa Efek Indonesia periode tahun 2018 dari situs website https://idx.co.id serta dengan menelusuri website perusahaan yang mempublikasikan laporan keberlanjutan perusahaan. Populasi pada penelitian ini adalah keseluruhan perusahaan sektor jasa yang terdaftar di Bursa Efek Indonesia tahun 2018 yang berjumlah 420 perusahaan jasa dengan teknik purposive sampling memilih kriteriakriteria :

Tabel 1. Kriteria Sampel

\begin{tabular}{clc}
\hline No. & \multicolumn{1}{c}{ Kriteria Sampel } & Jumlah \\
\hline 1 & Perusahaan jasa sektor perdagangan yang terdaftar di (BEI) & 420 \\
2 & Perusahaan jasa yang tidak membagi dividen pada & (313) \\
3 & perusahaan & Perusahaan jasa dengan laba komersial negatif \\
\hline Jumlah perusahaan sampel & 103 \\
\hline Sumber $:$ https://idx.co.id (diolah)
\end{tabular}

Alat analisis yang digunakan analisis linier berganda dengan SEM-PLS. Partial Least Square (PLS).

\section{HASIL DAN PEMBAHASAN \\ Hasil}


Adapun hasil uji significance of weight masing-masing nilai outer weight dari variabel observed terhadap variabel latennya adalah sebagai berikut:

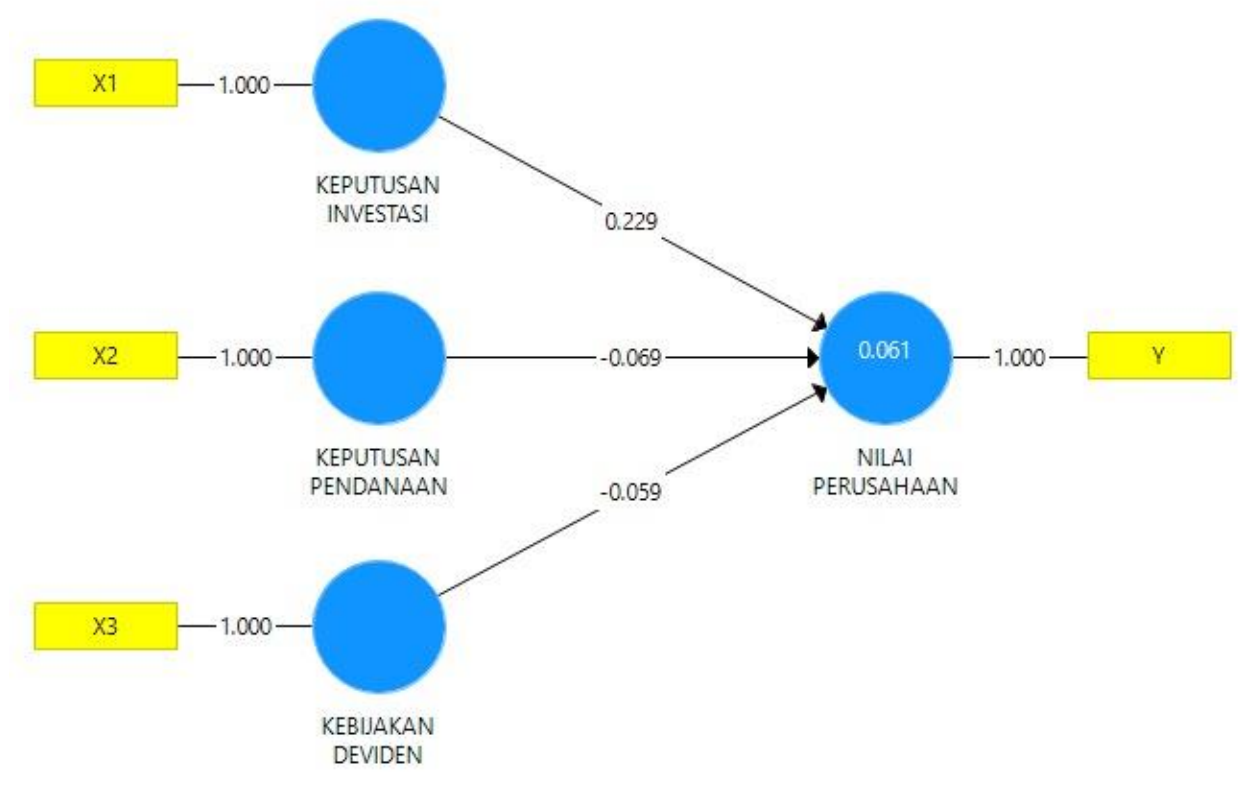

Gambar 1. Hasil uji significance of weight

Berdasarkan gambar diatas dapat diketahui bahwa nilai outer loading dari indikator pada masing-masing variabel lebih besar dari ketentuan yang telah ditetapkan yakni > 0,7. Hal ini berarti indikator pada masing-masing variabel tersebut mampu berkorelasi dan dapat menggambarkan variabelnya. Sehingga semua indikator pada masing-masing variabel dianggap layak untuk dilanjutkan dalam pengujian selanjutnya.

Tabel 2. $R$ Square

\begin{tabular}{l|rr}
\hline & R Square & \multicolumn{2}{c}{ R Square Adjusted } \\
\hline NILAI PERUSAHAAN & 0.061 & 0.032 \\
\hline
\end{tabular}

Sumber : Output PLS (2021)

Berdasarkan hasil pengujian yang sebagaimana ditunjukkan pada tabel tersebut, maka diketahui nilai $R$ Square untuk nilai perusahaan adalah sebesar 0.061 . Kemampuan variabel keputusan investasi, keputusan pendanaan, dan kebijakan dividen dalam menjelaskan nilai perusahaan adalah sebesar $6.1 \%$ dan sebesar $94.99 \%$ dijelaskan oleh variabel yang tidak diamati dalam penelitian ini.

Tabel 3.f Square 


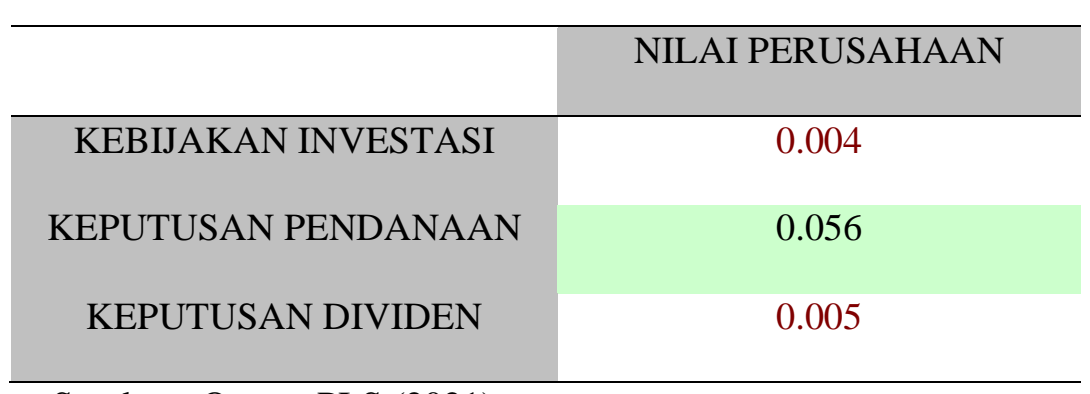

Sumber : Output PLS (2021)

Keputusan investasi memiliki pengaruh yang besar terhadap nilai perusahaan dengan nilai $f$ square sebesar 0.056 . sedangkan keputusan pendanaan dan kebijakan dividen memiliki pengaruh yang kecil terhadap nilai perusahaan dengan nilai $f$ square masing-masing sebesar 0.005 dan 0.004 .

Adapun hasil pengujian hipotesis dalam penlitian ini adalah sebagai berikut:

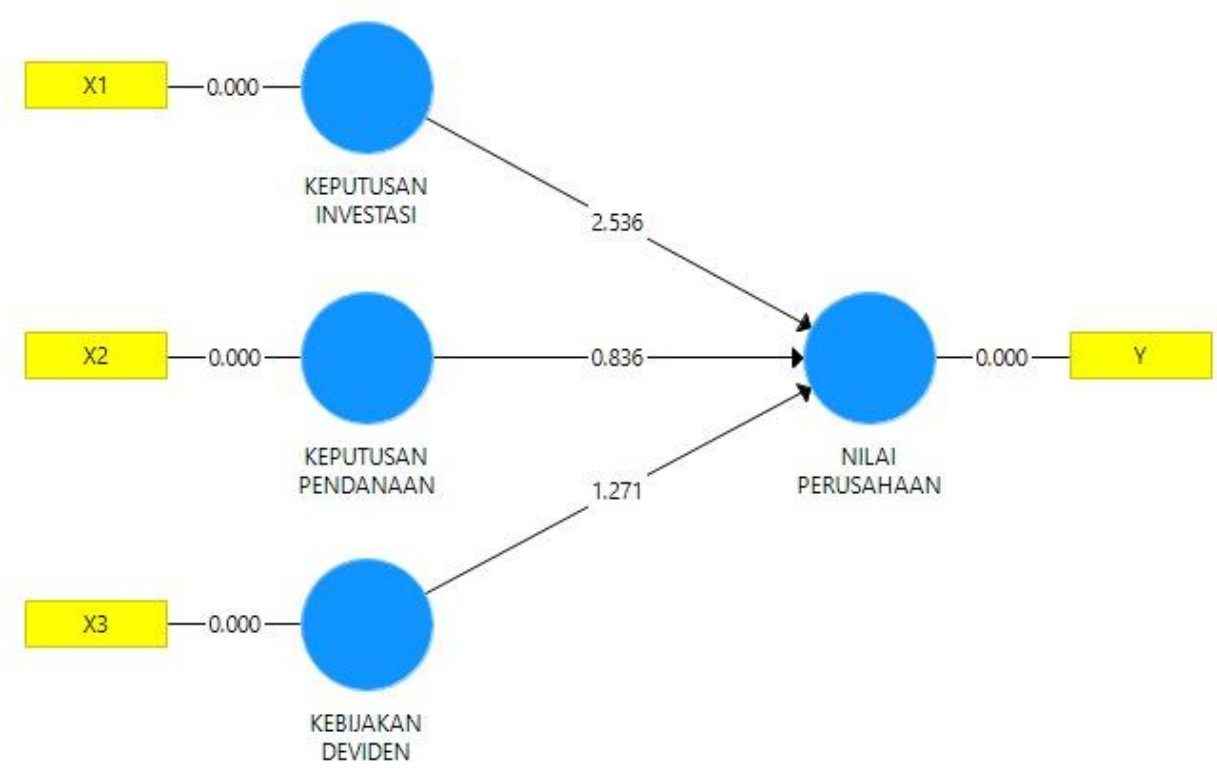

Gambar 2. Hasil Pengujian Hipotesis

Berdasarkan hasil pegujian yang sebagaimana yang ditunjukkan pada gambar tersebut dapat memberikan gambaran pengaruh antara variabel-variabel eksogen terhadap variabel-variabel endogen baik pengaruh secara langsung.

Tabel 4. path coefficients

\begin{tabular}{lll} 
Original & T Statistics & $\mathrm{P}$ \\
Sample $(\mathrm{O})$ & $(|\mathrm{O} / \mathrm{STDEV}|)$ & Values \\
\hline
\end{tabular}




\begin{tabular}{lccc}
\hline KEBIJAKAN DIVIDEN -> NILAI & -0.059 & 1.271 & 0.204 \\
$\begin{array}{l}\text { PERUSAHAAN } \\
\text { KEPUTUSAN INVESTASI -> NILAI }\end{array}$ & 0.229 & 2.536 & 0.012 \\
$\begin{array}{l}\text { PERUSAHAAN } \\
\text { KEPUTUSAN PENDANAAN -> NILAI }\end{array}$ & -0.069 & 0.836 & 0.404 \\
\hline PERUSAHAAN
\end{tabular}

Sumber : Output PLS (2021)

Berdasarkan hasil pengujian yang sebagaimana yang ditunjukkan pada tabel tersebut dapat memberikan gambaran nilai hasil kofisien jalur pengaruh secara langsung konstruk yang terbentuk melalui nilai original sample, $t$-statistics, dan $p$ value untuk menentukan hasil penelitian.

Pengaruh keputusan investasi terhadap nilai perusahaan memiliki koefisien korelasi bernilai positif sebesar 0.229 dengan nilai $t$ statistic sebesar 2.536 yang lebih besar dari nilai 1.960 dan nilai $p$ value sebesar 0.012 yang lebih kecil dari nilai 0.05 . Hal ini berarti keputusan investasi memiliki pengaruh positif dan signifikan terhadap nilai perusahaan. Hal ini menandakan hipotesis pertama diterima.

Pengaruh keputusan pendanaan terhadap nilai perusahaan memiliki koefisien korelasi bernilai negatif sebesar -0.069 dengan nilai $t$ statistic sebesar 0.836 yang lebih kecil dari nilai 1.960 dan nilai $p$ value sebesar 0.404 yang lebih besar dari nilai 0.05 . Hal ini berarti keputusan pendanaan tidak berpengaruh terhadap nilai perusahaan. Hal ini menandakan hipotesis kedua ditolak.

Pengaruh kebijakan dividen terhadap nilai perusahaan memiliki koefisien korelasi bernilai negatif sebesar -0.059 dengan nilai $t$ statistic sebesar 1.271 yang lebih kecil dari nilai 1.960 dan nilai $p$ value sebesar 0.204 yang lebih besar dari nilai 0.05. Hal ini berarti kebijakan dividen tidak berpengaruh terhadap nilai perusahaan. Hal ini menandakan kalau hipotesis ditolak.

\section{Pembahasan}

Hasil penelitian menemukan keputusan investasi memiliki pengaruh positif dan signifikan terhadap nilai perusahaan. Hal ini menandakan kalau hipotesis pertama diterima. Keputusan investasi perusahaan yang tinggi tinggi dapat memengaruhi investor tertarik berinvestasi. Investasi berperan penting dalam pengambilan keputusan Manajer demi keuntungan perusahaan di masa depan. Pendapat tersebut dapat diartikan bahwa untuk mencapai tujuan perusahaan, yaitu maksimalisasi nilai perusahaan dapat dicapai melalui kegiatan investasi karena semakin tinggi jumlah investasi perusahaan akan mengakibatkan laba perusahaan meningkat. Dengan meningkatknya laba, maka akan meningkatkan nilai perusahaan.

Hasil ini sesuai dengan dengan signaling theory yang menyatakan bahwa pengeluaran investasi memberikan sinyal positif tentang pertumbuhan perusahaan dimasa yang akan datang, sehingga meningkatkan harga saham sebagai indikator nilai perusahaan.

Hasil penelitian (Somantri \& Sukardi, 2019) dan (Kurniawan, 2020) mendukung penelitian ini bahwa keputusan investasi berpengaruh signifikan terhadap nilai perusahaan. Keputusan investasi harus dievaluasi dan dihubungkan dengan resiko dan hasil yang diharapkan, bagi investor, pertumbuhan perusahaan yang baik sangat menguntungkan karena modal yang diinvestasikan dapat memberikan pengembalian di masa depan (Effendy \& Handayani, 2020). 
Hasil penelitian menemukan keputusan pendanaan tidak berpengaruh terhadap nilai perusahaan. Pada teori trade off menjelaskan bahwa sebelum mencapai titik maksimum, hutang akan lebih murah daripada penjualan saham karena ada tax shield. Namun setelah mencapai titik maksimum, penggunaan hutang oleh perusahaan menjadi tidak menarik karena perusahaan harus menanggung biaya keagenan, biaya bunga, dan biaya kebangkrutan.

Mendukung hasil penelitian ini, (Salama et al., 2019) dan (Effendy \& Handayani, 2020) juga menemukan bahwa keputusan pendanaan tidak berpengaruh terhadap nilai perusahaan. Semakin tinggi perusahaan melakukan pendanaan dengan menggunakan utang, maka akan mengakibatkan nilai perusahaan menurun. Namun, hasil penelitian ini berbeda dengan temuan (Mubarokah \& Indah, 2021) dan (Fitiriawati et al., 2021) bahwa keputusan pendanaan berpengaruh terhadap nilai perusahaan artinya ketika pembiayaan didanai dari utang maka nilai perusahan akan mengalami kenaikan karena adanya faktor bebas pajak.

Hasil penelitian menemukan keputusan dividen tidak berpengaruh terhadap nilai perusahaan. Artinya kebanyakan investor berasumsi bahwa pembagian dividen yang besar tidak akan menjamin perusahaan terus bertumbuh di masa depan. Pembagian dividen tidak dapat menjamin bahwa perusahaan mendapatkan laba yang besar, perusahaan berpikir bahwa dengan laba, lebih baik menginvestasikannya pada proyek yang mempunyai prospek baik yang dapat meningkatkan laba.

Hasil ini juga sesuai dengan teori yang dikemukakan oleh Miller dan Modligiani yang menyatakan bahwa kebijakan dividen tidak memengaruhi nilai perusahaan karena menurut mereka rasio pembayaran dividen hanyalah rincian dan tidak memengaruhi kesejahteraan pemegang saham. Meningkatnya nilai dividen tidak selalu diikuti dengan meningkatnya nilai perusahaan. Karena nilai perusahaan ditentukan hanya oleh kemampuan perusahaan menghasilkan laba dari aset-aset perusahaan atau kebijakan investasinya. Perusahaan dapat membagikan dividen apabila pendapatan perusahaan dapat menutupi kekurangan sumber dana eksternal.

Hasil penelitian (Suryandani, 2018) dan (Effendy \& Handayani, 2020) mendukung temuan penelitian ini bahwa keputusan dividen tidak berpengaruh terhadap nilai perusahaan. Berapapun besar investasi yang akan ditanggung dimasa yang akan datang tidak berdampak pada nilai perusahaan karena dividen dianggap sebagai rincian yang tidak mempengaruhi kesejahteraan pemegang saham. Namun, berbeda dengan hasil penelitian (Salama et al., 2019) dan (Sugiyarti \& Ramadhani, 2019) menemukan bahwa keputusan dividen berpengaruh signifikan terhadap nilai perusahaan. Dengan membagikan laba bersih yang besar kepada pemegang saham dapat menyebabkan investor berlomba-lomba untuk membeli saham di perusahaan yang berdampak pada meningkatnya nilai perusahaan.

\section{KESIMPULAN}

Setelah melakukan pengujian pada data, maka hasil penelitian ini menemukan bahwa keputusan investasi berpengaruh signifikan terhadap nilai perusahaan. Sedangkan keputusan pendanaan dan keputusan dividen tidak berpengaruh terhadap nilai perusahaan. Hal ini berarti manajer perusahaan tidak terlalu mempertimbangkan keputusan pendanaan dan kebijakan dividen dalam mengukur nilai perusahaan.

\section{SARAN}


Penelitian selanjutnya diharapkan dapat memperluas variabel yang memengaruhi nilai perusahaan dan sampel pengamatan dengan periode lebih dari satu tahun.

\section{UCAPAN TERIMA KASIH}

Tim Penelitian ini mengucapkan terima kasih kepada Direktorat Riset dan Pengabdian Masyarakat, Deputi Bidang Penguatan Riset dan Pengembangan, Kementerian Riset dan Teknologi/Badan Riset dan Inovasi Nasional yang meberikan pendanaan melalui skema Penelitian Dosen Pemula tahun anggaran 2021 dan seluruh pihak yang mendukung pelaksanaan penelitian ini.

\section{DAFTAR PUSTAKA}

Ayuningtyas, Y., Wiyani, W., \& Susilo, E. A. (2020). KEBIJAKAN HUTANG, KEPUTUSAN INVESTASI, DAN PROFITABILITAS DALAM MENGUNGKIT NILAI PERUSAHAAN. Jurnal Bisnis Dan Manajemen, 7(1).

Bahrun, M. F., Tifah, T., \& Firmansyah, A. (2020). Pengaruh Keputusan Pendanaan, Keputusan Investasi, Kebijakan Dividen, Dan Arus Kas Bebas Terhadap Nilai Perusahaan. Jurnal Ilmiah Akuntansi Kesatuan, 8(3), 263-276.

Chasanah, A. N., \& Adhi, D. K. (2018). Profitabilitas, struktur modal dan likuiditas pengaruhnya terhadap nilai perusahaan pada perusahaan real estate yang listed di BEI tahun 2012-2015. Fokus Ekonomi: Jurnal Ilmiah Ekonomi, 12(2), 109-128.

Effendy, N. N., \& Handayani, N. (2020). Pengaruh Keputusan Investasi, Keputusan Pendanaan, Dan Kebijakan Dividen Terhadap Nilai Perusahaan. Jurnal Ilmu Dan Riset Akuntansi (JIRA), 9(3).

Febriana, E., \& Djawahir, A. H. (2016). Pengaruh Struktur Modal, Kebijakan Dividen, Ukuran Perusahaan, Kepemilikan Saham Manajerial dan Profitabilitas Terhadap Nilai Perusahaan (Studi pada Perusahaan Manufaktur yang Terdaftar di BEI Pada 2011-2013). Ekonomi Bisnis, 21(2), 163-178.

Fitiriawati, F. D., Wulandari, R., \& Sari, A. R. (2021). ANALISIS PENGARUH KEPUTUSAN INVESTASI, KEPUTUSAN PENDANAAN DAN KEBIJAKAN DEVIDEN TERHADAP NILAI PERUSAHAAN DENGAN UKURAN PERUSAHAAN SEBAGAI VARIABEL MODERASI. Jurnal Riset Mahasiswa Akuntansi, 9(1).

Kurniawan, M. Z. (2020). Analisis Keputusan Investasi, Keputusan Pendanaan, Dan Kebijakan Dividen Terhadap Nilai Perusahaan Indeks LQ-45. Ekonika: Jurnal Ekonomi Universitas Kadiri, 5(1), 113-122.

Languju, O. (2016). Pengaruh return on equity, ukuran perusahaan, price earning ratio dan struktur modal terhadap nilai perusahaan property and real estate terdaftar di Bursa Efek Indonesia. Jurnal Berkala Ilmiah Efisiensi, 16(2).

Mubarokah, F., \& Indah, N. P. (2021). Pengaruh Keputusan Investasi, Pendanaan, dan Dividen Terhadap Nilai Perusahaan Periode 2014-2018. Coopetition: Jurnal Ilmiah Manajemen, 12(2), 163-180.

Purnomo, E. (2019). Pengaruh Profitabilitasdan Leverage Terhadap Nilai Perusahaan Dengan Struktur Modal Sebagai Variabel Intervening. Jurnal Ekobis Dewantara, 1(12), 78-97.

Ramadhani, H. (2016). Analisis Price Book Value Dan Return On Equity Serta Deviden Payout Ratio Terhadap Price Earning Ratio. Forum Ekonomi, 18(1).

Rinnaya, I. Y., Andini, R., \& Oemar, A. (2016). pengaruh profitabilitas, rasio aktivitas, keputusan pendanaan keputusan investasi terhadap nilai perusahaan (studi empiris pada perusahaan manufaktur yang terdaftar di BEI tahun 2010-2014). Journal Of Accounting, 2(2).

Salama, M., Van Rate, P., \& Untu, V. N. (2019). Pengaruh keputusan investasi, keputusan pendanaan dan kebijakan dividen terhadap nilai perusahaan pada industri perbankan yang terdaftar di bei periode 2014-2017. Jurnal EMBA: Jurnal Riset Ekonomi, Manajemen, Bisnis Dan Akuntansi, 7(3). 
Somantri, I., \& Sukardi, H. A. (2019). Pengaruh Keputusan Investasi, Kebijakan Hutang Dan Kebijakan Dividen Terhadap Nilai Perusahaan. Jurnal Ekonomi Manajemen Perbankan (JEMPER), 1(1), 1-10.

Sugiyarti, L., \& Ramadhani, P. (2019). Agresivitas Pajak, Keputusan Pendanaan dan Kebijakan Deviden Terhadap Pengukuran Nilai Perusahaan. Jurnal Akuntansi Trisakti, 6(2), 233-244.

Suryandani, A. (2018). Pengaruh pertumbuhan perusahaan, ukuran perusahaan, dan keputusan investasi terhadap nilai perusahaan pada perusahaan sektor property dan real estate. Business Management Analysis Journal (BMAJ), 1(1), 49-59.

Wildan, M., \& Yulianti, N. W. (2021). PENGARUH KEPUTUSAN KEUANGAN, STRATEGI DIVERSIFIKASI, EFISIENSI OPERASIONAL DAN INOVASI TERHADAP NILAI PERUSAHAAN. JURNAL AKUNTANSI, 1(1), 16-29. 